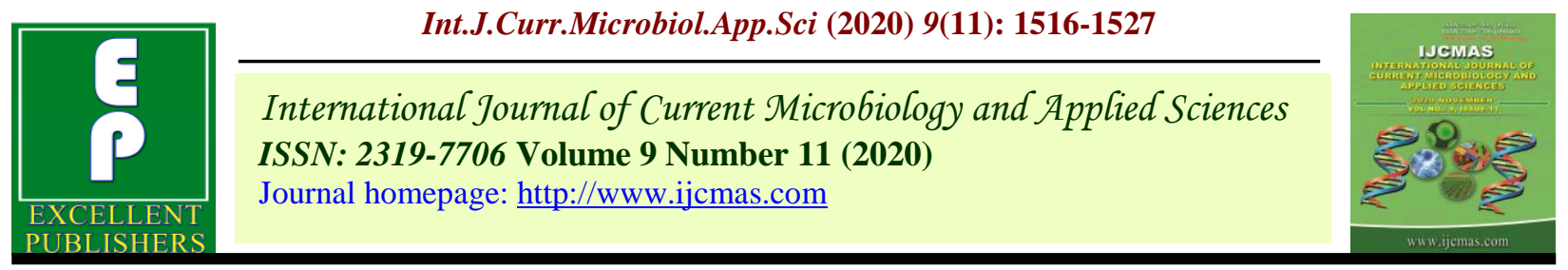

Original Research Article

https://doi.org/10.20546/ijcmas.2020.911.180

\title{
Suitability of Targeted Yield Equations Evolved for MTU-1010 to Other Similar Rice Cultivars in Chhattisgarh
}

\author{
Monika Tikariha*, V. N. Mishra, L. K. Srivastav, R. Banwasi and G. K. Jatav
}

Indira Gandhi Krishi Vishwavidyalaya, Raipur (C.G), India

*Corresponding author

Ke y w o r d s
MTU-1010,
Rice Cultivars,
Oryza sativa

\section{A B S T R A C T}

Field experiment was conducted to study the suitability of targeted yield equations evolved for MTU-1010 to other similar rice cultivars during kharif season, 2019 at the research farm of Inidira Gandhi Krishi Vishwavidyalaya, Raipur, C.G. Experiment was laid out in strip plot design having five treatments in each strip replicated thrice. The treatments consisted of eight rice varieties as strip and five treatments $T_{1}$ - Fertilizer application for Yield Target (YT) of $60 \mathrm{t} / \mathrm{ha} ; \mathrm{T}_{2^{-}}$YT $50 \mathrm{t} / \mathrm{ha}$; $\mathrm{T}_{3}-$ Control (No NPK application), $\mathrm{T}_{4^{-}}$FYM (5 t/ha) and $\mathrm{T}_{5}$-GRD (120:60:40 $\left.\mathrm{kg} \mathrm{ha}^{-1} \mathrm{NPK}\right)$. The results revealed that IGKV-R2, Karma Masuri, Mahamaya and IR-64 varieties have successfully achieved the yield targets from the fertilizer prescription equation evolved for MTU-1010. The efficiencies of fertilizer N, $\mathrm{P}$ and $\mathrm{K}$ were higher with targeted yield-based treatments followed by GRD and FYM application. However, higher benefit cost ratio (BCR) was observed in GRD (120:60:40 kg of fertilizer $\mathrm{N} \mathrm{P} \mathrm{K} \mathrm{kg/ha)} \mathrm{due} \mathrm{to} \mathrm{application} \mathrm{of} \mathrm{inorganic} \mathrm{fertilizer} \mathrm{N}, \mathrm{P}$ and $\mathrm{K}$ without FYM as compared to STCR yield target of 60 and $50 \mathrm{q} / \mathrm{ha}$ which received fertilizer application with 5 t/ha FYM and high cost of FYM applied was also included with cost of inorganic fertilizers contributed higher BCR. It can be concluded from the study that the STCR based fertilizer prescription evolved for MTU 1010 variety of rice can be used for four varieties of rice under study i.e. IGKV-R2, Karma Masuri, Mahamaya and IR-64.

\section{Introduction}

Rice (Oryza sativa) is the most important staple food grain of more than half of the population over the world. It is an important target to provide food security and livelihoods for millions of people. Rice fulfils 43 percent of the caloric requirement for more than 7075 percent of the Indian population. The Chhattisgarh state has about 3.7 million ha area under rice cultivation which is mostly rainfed covering both uplands and shallow lowlands. The state average productivity is about 2.3 ton/ha. To congregate the demands of raising population and to maintain selfsufficiency, the present production level of 111 million tons of rice must be increased to 125 million tons by the year 2025. This rate of increase signifies the contribution of fertilizers to the production of rice to meet the food requirements of the hungry mouths of the country. To achieve food security, balanced fertilization based on soil testing has to be generated for all crops and their 
varieties released time to time by various research institutes and universities. Green revolution in India witnessed phenomenal increase in fertilizer consumption. The main cause for decline of rice productivity is increased public concern for the protection of environmental resource. This might be due to indiscriminate nutrient management which is one of the important reasons for environment degradation.In Indian context, soil fertility status depleted due to inadequate and imbalanced use of plant nutrients through fertilizers and manures. Fertilizer is one of the most expensive inputs in agriculture, and using the right amount of fertilizer is necessary for the farm's profitability and environmental protection. Due to rising input costs and falling commodity prices, farmers are currently looking for new ways to increase input efficiency and reduce cost of production. Soil testing is the most widely used in research and advisory tool for making balanced and profitable fertilizer recommendation. The most appropriate balance and economical doses of fertilizers can be developed based on soil testing and crop response studies. Soil test values supplemented with soil test crop response data, cropping system, soil survey information and management conditions can be used as guide to predict crop fertilizer needs in a given situation.

The introduction and rapid increase of high yielding varieties of the crops, the need for systematic soil test crop response research in different agro-climatic regions become evident. ICAR established the All India Coordinated Research Project on Soil Test Crop Response Correlation in 1967 and the STCR concept was developed by Ramamoorthy, in 1987. STCR provides the relationship between a soil test value and crop yield with fertilizer application. An inductive approach in soil test calibration provide a strong base for giving sound advice to farmers for promoting fertilizer use efficiency for balanced fertilization and soil fertility maintenance. The essential parameters for Targeted yield concept are (i) nutrient requirement in $\mathrm{kg}$ /quintal of grain production (NR), (ii) percent contribution of soil available nutrients (CS), fertilizer nutrients (CF) and organic source (COrg). Using these basic parameters, STCR has developed many information on soil test-based fertilizer application for achieving different yield target and till now major crops like cereals, pulses, vegetables, cash crops have been covered. Since rice is a main crop of the state and STCR based fertilizer recommendations have been generated for many varieties of rice. Generating this information for each crop/variety, at least two season/years' time takes place and one season requires for its testing suitability, validation and precision. The different varieties of the same crop may perform similarly or differently with the same dose of fertilizer application. It may be quite worthy if field testing is done with many varieties of the same crop (Rice) using the fertilizer recommendation of any standard rice variety already evolved and if some varieties perform similar manner then STCR equations can be applied for such similar varieties to analyze the economics of these models for their adoption to enhance productivity and profitability in rice-rice crop sequences. In view of this, a field study was performed for suitability testing of a fertilizer prescription equations evolved for MTU 1010 to other rice varieties popular among the farmers.

\section{Materials and Methods}

The experiment was conducted in research farm of Indira Gandhi Krishi Vishwavidyalaya, Raipur (C.G) which was based on STCR targeted yield approach. In this study, STCR based fertilizer application for MTU 101 variety of rice was used and tested the same to other seven varieties for 
their suitability. Before conducting this trial, the field was divided in to three long strips and labeled as $\mathrm{L}_{0}, \mathrm{~L}_{1}, \mathrm{~L}_{2}$ which were considered as replication and had fertility variation with respect to major nutrients to observe the performance of various rice varieties who received a definite dose of fertilizer based on soil nutrients level to achieve a definite yield target.The experimental soil was Vertisol (medium black) represented as Udic Chromustert typical fine montmorillonitic, thermic and clayey textured. The initial soil available nutrients of NPK are presented in Table 1. The experiment comprised of eight different rice cultivars on the basis of their popularity in the state whereas MTU-1010 taken as a standard check. Treatment consisted of $\mathrm{T}_{1^{-}}$ (fertilizer application with FYM for yield target (YT) of $6.0 \mathrm{t} / \mathrm{ha}), \mathrm{T}_{2^{-}}$(YT of $5 \mathrm{t} / \mathrm{ha}$ ), T3- (Control), T4- (5 ton/ha FYM), T5(General Recommended Dose (GRD) of fertilizer NPK as 120:60:40 kg /ha) with three replication and Experiment was laid out in strip plot design.

Fertilizer prescription equations for MTU1010 rice variety developed under STCR, centre Raipur were used for the calculation of the doses of fertilizer and manure for testing on other rice varieties.

$\begin{array}{lll}\text { Nitrogen } & \mathrm{FN}=4.05 \mathrm{~T}- & 0.57 \mathrm{SN} \quad- \\ \text { 0.78FYM } & & \end{array}$

Phosphorous FP= 1.46T- 3.09SP - 0.31FYM

Potassium FK $=1.61 \mathrm{~T}-0.10 \mathrm{SK} \quad-$ $0.14 \mathrm{FYM}$

Where, FN, FP and $\mathrm{FK}$ are fertilizer $\mathrm{N}, \mathrm{P}_{2} \mathrm{O}_{5}$ and $\mathrm{K}_{2} \mathrm{O}$ (Kg ha-1) respectively. FYM is Farm Yard Manure (t ha- $\left.{ }^{1}\right)$. SN, SP and SK are soil test values $\left(\mathrm{kg} \mathrm{ha}^{1}\right)$ for $\mathrm{KMnO} 4 \mathrm{~N}$, Olsen's $\mathrm{P}$ and ammonium acetate extractable $\mathrm{K}$ and $\mathrm{Y}$ is crop yield in $\mathrm{q} / \mathrm{ha}$.
Based on initial soil test value, fertilizer to be applied were calculated using above equations as presented in Table 1.

\section{Results and Discussion}

\section{Plant height}

Data presented in Table 2 revealed that there was marked significant difference in plant height at various treatments at all the stages except 30 DAS where it did not differ significantly. The maximum plant height (53.2, 101.0 and $109.8 \mathrm{~cm}$ at 30,60 and 90 DAT (Days After Transplanting), respectively were recorded in treatment $T_{1}$ which received fertilizer based on soil test to achieve $6.0 \mathrm{t} \mathrm{ha}$ 1 yield target. Lowest plant height was recorded under control where no fertilizer was applied. Plant height significantly influenced by different rice varieties. Significantly highest plant height was recorded with $\mathrm{V}_{4-}$ Karma masuri at 30, 60, 90 DAT followed by $\mathrm{V}_{8}$ Indira Aerobic at all growth stages of crop. Lowest plant height was recorded under V6 IR-36 at all growth stages of crop. The differences in plant height of various rice cultivars depends upon their genetic ability as well as varying response to nutrient management practices which might have led to variation in plant height (Choudhary et al., 2010).

\section{Number of effective tillers $\mathrm{m}^{-2}$}

Effective tillers affected significantly with different rice cultivars and fertilizer treatments. Four rice cultivars of rice (Karma Masuri, Indira Aerobic, Mahamaya and IGKV R2) had higher effective tillers which were statistically at par. Next group of rice varieties which had similar number of effective tillers wereF56 Prota Zin, IR-64 and, MTU- 1010 and showed no difference significantly. IR-36 variety of rice showed significantly lowest number of effective tillers. Application of 
fertilizer for yield targets of 60 and $50 \mathrm{q} / \mathrm{ha}$ and GRD showed highest number of effective tillers (271, 261 and 266) and were statistically at par. Application of 5t/ha FYM gave 176 effective tillers which was significantly lower than those of earlier treatments discussed. The treatment which did not receive any nutrients (control) had significantly lowest effective tillers but was at par with FYM application. Similar findings also reported in Karki et al., (2018), Awan et al., (2011). The increment in number of tillers with NPK and FYM can be attributed to soil conditions with more availability and uptake of nutrients, water and growth promoting substances to promote more tillers. Similar findings have been also reported by Srivastava et al., (2013), Tabar et al., (2012) and Mahmud et al., (2016).

\section{Number of filled grain per panicle}

Filled grains affected significantly with different rice cultivars and fertilizer treatments. Highest number of filled grains was recorded with IGKV R2 variety followed by MTU -1010, Mahamaya and Karma Masuri which gave maximum yields as the yield goal testing.IR -64 variety also gave higher number of filled grains which yielded as per the STCR yield target. Fertilizer application had significant effect on number of filled grains and $T_{1}$ which received the fertilizer application to achieve a yield goal of $60 \mathrm{q} / \mathrm{ha}$ produced significantly highest number of filled grains followed by $\mathrm{T}_{5}, \mathrm{~T}_{2}, \mathrm{~T}_{4}$ and $\mathrm{T}_{3}$.

Application of FYM @ 5t/ha gave 105 filled grains which was significantly lower than those of formers treatments. The treatment which did not receive any nutrients (control) had significantly lowest filled grains (95). This result consistent with many workers like Shekara et al., (2011); Patel et al., (2012); Karki et al., (2018)

\section{Test weight}

Test weight of rice varieties differed significantly and highest weight of 1000 grains was recorded with Mahamaya followed by three cultivars (F56 Prota Zin, MTU-1010 and IGKV R2), IR-64, IR-36, Indira Aerobic and last Karma Masuri gave lowest test weight (21.12 g). Mahamaya variety of rice is a bold and medium slender rice whereas Karma Masuri is a fine and small sized character. Fertilizer application had significant impact on test weight as can be noticed from there result that in case of control treatment that reduced the grain weight. Other researchers found similar findings Chand et al., (2016).

\section{Grain yield}

Significantly higher mean grain yields were recorded with IGKV R2 and Mahamaya which were statistically at par followed by Karma Masuri, MTU-1010 and IR-64 and differences among these three were nonsignificant.F56 Prota Zin, IR-36 and Indira Aerobic were the next lower yielder group and had statistically similar yields. If we compare the mean grain yields among the fertilizer treatments then significantly highest grain yield (59.72 q/ha) was observed with the fertilizer application to achieve a yield target of $60 \mathrm{q} / \mathrm{ha}\left(\mathrm{T}_{1}\right)$ followed by $\mathrm{T}_{2}(50 \mathrm{q} / \mathrm{ha}$ YT), $\mathrm{T}_{5}$ (GRD), $\mathrm{T}_{4}$ (FYM) and $\mathrm{T}_{3}$ (control). Application of 5 t/ha FYM gave $28.14 \mathrm{q} / \mathrm{ha}$ yield which was significantly lower than earlier treatments.

The interpretation of the data on grain yield performance to different fertilizer treatments clearly show that the testing of STCR based fertilizer prescription equation developed for MTU-1010 is valid for the rice varieties of IGKV R2, KarnmaMasuri, Mahamaya and IR-64 which have fulfilled the desired targeted yields hence one fertilizer equations 
evolved for MTU-1010 can be used for these four rice varieties. Results have clearly indicated that these four varieties have achieved the yield targets of 60 and 50q/ha. Other varieties tested under study like F56 Prota Zin and Indira Aerobic could not achieve the targeted yields. Fertilizer application based on GRD (120:60:40) has approached the yield level up to $50 \mathrm{q} / \mathrm{ha}$. Application of only 5t/ha FYM recorded the mean yield level up to $28 \mathrm{q} / \mathrm{ha}$ and can contribute about $4 \mathrm{q} / \mathrm{ha}$ due to FYM application after deducting the yield from control treatment. Thus, the balanced use of fertilizer in combination with FYM is necessary for sustaining soil fertility and productivity of crop. Similar findings were also reported by Basavraj et al., (2016), Dastan et al., (2012), Subehia and Sepehya (2012), Gautam et al., (2013) and Mahmud et al., (2016).

\section{Nitrogen uptake}

Nutrient uptake by rice crop is given in Table3. IGKV R2 variety of rice recorded significantly higher $\mathrm{N}$ uptake $\left(82.8 \mathrm{~kg} \mathrm{~N} \mathrm{ha}^{-1}\right)$ followed by Karma Masuri (78.6 $\mathrm{kg} \mathrm{N} \mathrm{ha}^{-1}$ ), MTU-1010 (76.9 kg N ha ${ }^{-1}$ ), Mahamaya and IR-64. These cultivars have the potential to yield the desired level as per the required fertilizer application to achieve the targeted yields in spite of variable $\mathrm{N}$ uptake. Treatment $T_{1}$ that received highest fertilizer dose for $60 \mathrm{q} / \mathrm{ha}$ yield goal has shown significantly higher $\mathrm{N}$ uptake followed by $\mathrm{T}_{2}$, $\mathrm{T}_{5}, \mathrm{~T}_{4}$ and $\mathrm{T}_{3}$.

Total $\mathrm{N}$ uptake followed the trends as recorded with grain and straw yields since uptake is a multiple of yield and content. The increase in total uptake observed with increasing $\mathrm{N}$ input because of better availability of nitrogen in the soil or due to healthier roots and greater density (Belete et al., 2018).
Improvement in $\mathrm{N}$ uptake with increased $\mathrm{N}$ levels was reported by Sandhu and Mahal (2014). Hossain et al., (2010) also reported higher $\mathrm{N}$ uptake in rice with FYM application over no fertilizer and inorganic fertilizers application

\section{Phosphorous uptake}

Highest $\mathrm{P}$ uptake was recorded by MTU1010(11.95 kg P ha $\left.{ }^{-1}\right)$ followed by F56 Prota Zin (11.67 kg $\mathrm{P} \mathrm{ha}{ }^{-1}$ ), IGKV R2, Karma Masuri and Mahamaya which behaved differently in $\mathrm{N}$ uptake. Total $\mathrm{P}$ uptake had variable $\mathrm{P}$ absorption trends as the $\mathrm{P}$ requirement of various varieties might have differently. However, $\mathrm{T}_{1}$ Treatment that received highest fertilizer dose for $60 \mathrm{q} / \mathrm{ha}$ yield goal had absorbed significantly higher $\mathrm{P}$ followed by GRD(T5), 50q/ha(T2), FYM (T4) and lowest $\mathrm{P}$ uptake was recorded in control (T3) where no fertilizer was applied. Hossain et al., (2010) also reported higher $\mathrm{P}$ uptake in rice with FYM application over no fertilizer and inorganic fertilizers application. Siddaram et al., (2011) recorded significantly higher phosphorus uptake with recommended dose of fertilizer (100:50:50) + 10 t of FYM ha-1 over control which was on par with $150 \%$ and $200 \%$ recommended dose of nitrogen.

\section{Potassium uptake}

Significantly highest $\mathrm{K}$ uptake was recorded with IGKV R2 (107.8 $\left.\mathrm{kg} \mathrm{K} \mathrm{ha}{ }^{-1}\right)$ cultivar followed three cultivars (Karma Masuri, MTU-1010 and IR-64) which were at par and had almost similar K uptake. Mahamaya (90.2 $\mathrm{kg} \mathrm{K}$ ha-1) and F56 Prota Zn and IR -36 varieties had the next order in $K$ uptake followed by Indira Aerobic. With regard to fertilizer treatments, significantly higher $\mathrm{K}$ uptake was recorded by $\mathrm{T}_{1}$ that received the fertilizer to achieve the yield target of $60 \mathrm{q} / \mathrm{ha}$ (127.2 $\mathrm{kg} \mathrm{K} \mathrm{ha}^{-1}$ ) followed by $\mathrm{T}_{5}$ (GRD), $\mathrm{T}_{2}$ 
(50 q/haYT), $\mathrm{T}_{4}$ (FYM) and $\mathrm{T}_{3}$ (Control). The potassium requirement of rice varied with $\mathrm{K}$ availability in soil and its application. The experimental field soil was well supply in $\mathrm{K}$ status and absorbed in luxury way. Hence, its trends were not in a certain way. Many other scientists have also found the higher $\mathrm{K}$ uptake with high targeted yield of many crops. Pradeep et al., (2012) also concluded that application of recommended dose of fertilizer + FYM @ 10t ha-1 recorded significantly higher potassium (94.0kg ha-1) uptake. Ibajanai (2017) concluded that the total K uptake under the treatment involving STCR approach for targeted yield of 25 and $35 \mathrm{q}$ ha1 with and without FYM was statistically higher as compared to general recommended dose and soil test based treatment.

\section{Nutrient use efficiency}

\section{$\mathrm{N}$ use efficiency}

The highest NUE was recorded in Karma Masuri (41.5 \%) followed by IGKV R2 (31.8), MTU-1010 (37.2), Mahamaya (36.7), IR 64 (33.6), F56 Prota Zin (32.4), Indira aerobic (32.1) and IR-36 (29.6\%). With respect to fertilizer treatments, $\mathrm{T}_{1}$ that received fertilizer $\mathrm{N}$ (avg. $166 \mathrm{~kg} \mathrm{~N} / \mathrm{ha}$ ) recorded higher NUE (41.4 \%) followed by $40.3 \%$ by $\mathrm{T}_{2}$ that received fertilizer $\mathrm{N}$ (avg $122 \mathrm{~kg} / \mathrm{ha}$ ) and $\mathrm{T}_{3}$ that received fertilizer $\mathrm{N} @$ $120 \mathrm{~kg} \mathrm{~N} / \mathrm{ha}$.

Application of $5 \mathrm{t} / \mathrm{ha}$ FYM exhibited low efficiency of $\mathrm{N}(20.3 \%)$ being a bulky nature of organic manure and low $\mathrm{N}$ content $(0.50$ $\%)$. In general, efficiency increases with lower fertilizer $\mathrm{N}$ and decreases with higher dose. Contrary to this, higher NUE with high fertilizer dose was observed with $\mathrm{T}_{1}$ treatment that received higher dose of fertilizer $\mathrm{N}$ followed by $T_{2}$ and $T_{5}$. The reason behind this seems to be the exact doses of fertilizer application based on STCR concept which deals with as per the $\mathrm{N}$ requirement of the crop. The blanket recommendation of fertilizer N@120 kg/ha also matched the treatment $\mathrm{T}_{2}$ which received the fertilizer $\mathrm{N}$ @ $122 \mathrm{~kg} \mathrm{~N} / \mathrm{ha}$. The split application of nitrogen $(1 / 4$ at sowing, $1 / 2$ at tillering and $1 / 4$ at booting) produced the highest nitrogen use efficiency traits as reported by Belete et al., (2018). Similar finding were also reported by Sathish et al., (2011) and Ramalakshmi et al., (2012).

\section{$P$ use efficiency}

Highest PUE was recorded with Karma Masuri (21.3\%) followed by IR-64, MTU 1010, Mahamaya, F56 ProtaZin, IR-36 and Indira Aerobic rice. Fertilizer P applied (avg $39 \mathrm{~kg} \mathrm{P} \mathrm{O}_{5} / \mathrm{ha}$ ) for $60 \mathrm{q} / \mathrm{ha}$ yield target-based application $\left(\mathrm{T}_{1}\right)$ resulted higher PUE $(22.1 \%)$ followed by $20.4 \%$ PUE with $\mathrm{T}_{2}(50 \mathrm{q} / \mathrm{ha}$ yield target and received avg $20 \mathrm{~kg} \mathrm{P}_{2} \mathrm{O}_{5} / \mathrm{ha}$ ) and $18.2 \%$ PUE was received with application of $60 \mathrm{~kg} \mathrm{P}_{2} \mathrm{O}_{5} / \mathrm{ha}$ treated as GRD in $\mathrm{T}_{5}$ treatment. FYM application @ 5t/ha recorded low recovery of $\mathrm{P}(15.2 \%)$ due to its bulky nature and low $\mathrm{P}$ content $(0.30 \%)$. Application of fertilizer goes towards soil reaction and reacts with dominant cations present soil like $\mathrm{Ca}, \mathrm{Fe}$, and $\mathrm{Al}$ and convert in to insoluble forms. Many researchers have also reported the similar results in PUE (Swarup et al., 2006, Banik et al., 2006).

\section{K use efficiency}

Highest KUE recorded in MTU-1010 was significant at par with IR-64, Karma Masuri, IGKV-R2. However, other varieties like IR36, Mahamaya, Indira Aerobic and F56 Prota Zin have showed lower efficiency of $\mathrm{K}$. Highest KUE recorded in Fertilizer $\mathrm{K}$ for GRD based application (T5) resulted higher KUE followed by T1 (60q/ha yield target) and T2 (50 q/ha yield target). 
Table.1 Soil test values for available N, P and K and fertilizer nutrients required for targeted yield of rice

\begin{tabular}{|c|c|c|c|c|c|c|c|c|c|}
\hline \multirow{2}{*}{$\begin{array}{l}\text { Fertility } \\
\text { strip/ } \\
\text { Replica-tion }\end{array}$} & \multirow{2}{*}{$\begin{array}{c}\text { Av }-\mathrm{N} \\
\mathbf{k g} \\
\mathbf{h a}^{-1}\end{array}$} & \multicolumn{2}{|c|}{$\begin{array}{c}\mathbf{N}\left(\mathrm{kgha}^{-1}\right) \\
\text { Applied for }\end{array}$} & \multirow{2}{*}{$\begin{array}{c}\operatorname{Av} P \\
\mathbf{k g}^{-1}\end{array}$} & \multicolumn{2}{|c|}{$\mathrm{P}_{2} \mathrm{O}_{5} \mathrm{~kg} \mathrm{ha}^{-1}$ applied for } & \multirow{2}{*}{$\underset{\mathbf{k g}^{-1}}{\mathrm{Av} \mathrm{K}}$} & \multicolumn{2}{|c|}{$\mathrm{K}_{2} \mathrm{O} \mathrm{kg} \mathrm{ha}^{-1}$ applied for } \\
\hline & & 50 q/ha YT & 60 q/ha YT & & 50 q/ha YT & 60 q/ha YT & & 50 q/ha YT & 60 q/ha YT \\
\hline $\mathbf{L}_{0} / \mathbf{R}_{1}$ & 125 & 120 & 160 & 10.5 & 31 & 46 & 330 & 44 & 60 \\
\hline $\mathbf{L}_{2} / \mathbf{R}_{\mathbf{3}}$ & 125 & 120 & 160 & 17.6 & 09 & 23 & 352 & 42 & 58 \\
\hline GRD & - & \multicolumn{2}{|c|}{120} & - & \multicolumn{2}{|c|}{60} & - & \multicolumn{2}{|c|}{40} \\
\hline
\end{tabular}

Table.2 Effect of nutrient management approaches on plant height, Number of Effective tillers $/ \mathrm{m}^{2}$, Number of filled grain per panicle, 1000 -grain weight, grain \& straw yield of rice

\begin{tabular}{|c|c|c|c|c|c|c|c|c|}
\hline \multirow[t]{2}{*}{ Treatments } & \multirow{2}{*}{$\begin{array}{l}\text { Number of } \\
\text { effective } \\
\text { tillers } / \mathrm{m}^{2}\end{array}$} & \multicolumn{3}{|c|}{ Plant height } & \multirow{2}{*}{$\begin{array}{l}\text { Number of } \\
\text { filled } \\
\text { grains/panicle }\end{array}$} & \multirow{2}{*}{$\begin{array}{l}\text { Test Weight } \\
\text { g/1000 seed }\end{array}$} & \multirow{2}{*}{$\begin{array}{l}\text { Grain } \\
\text { yield }\end{array}$} & \multirow{2}{*}{$\begin{array}{l}\text { Straw } \\
\text { yield }\end{array}$} \\
\hline & & 30DAT & 60DAT & 90DAT & & & & \\
\hline \multicolumn{9}{|l|}{ Horizontal Strips: Fertilizer Treatment (5) } \\
\hline $\begin{array}{l}\text { T1 Fertilizer dose for yield Target } 6 \text { ton/ ha + } \\
\text { FYM }\end{array}$ & $321 \mathrm{a}$ & $53.2 \mathrm{a}$ & $101.0 \mathrm{a}$ & $109.8 \mathrm{a}$ & $143 \mathrm{a}$ & $26.69 \mathrm{a}$ & $59.72 \mathrm{a}$ & $70.07 \mathrm{a}$ \\
\hline $\begin{array}{l}\text { T2 Fertilizer dose for yield Target } 5 \text { ton/ ha + } \\
\text { FYM }\end{array}$ & $311 \mathrm{~b}$ & $51.9 \mathrm{a}$ & $99.2 \mathrm{~b}$ & $107.7 \mathrm{~b}$ & $133 \mathrm{c}$ & $26.71 \mathrm{a}$ & $50.15 \mathrm{~b}$ & $58.42 \mathrm{~b}$ \\
\hline T3Control (No fertilizer) & $216 d$ & $41.4 \mathrm{c}$ & $83.3 \mathrm{e}$ & $88.1 \mathrm{e}$ & $95 \mathrm{e}$ & $25.54 \mathrm{c}$ & $23.86 \mathrm{e}$ & $26.23 \mathrm{e}$ \\
\hline T4 FYM@5 t ha & $246 c$ & $44.5 \mathrm{~b}$ & $86.3 \mathrm{~d}$ & $91.4 \mathrm{~d}$ & $105 \mathrm{~d}$ & $26.12 \mathrm{~b}$ & $28.10 \mathrm{~d}$ & $32.80 \mathrm{~d}$ \\
\hline T5 GRD 12:60:40 & $315 \mathrm{ab}$ & $52.6 \mathrm{a}$ & $97.6 \mathrm{c}$ & $106.3 \mathrm{c}$ & $137 \mathrm{~b}$ & $26.30 \mathrm{ab}$ & $46.90 \mathrm{c}$ & $54.04 \mathrm{c}$ \\
\hline CD $(5 \%)$ & 8.56 & 2.70 & 1.53 & 1.91 & 1.36 & 0.30 & 1.27 & 1.78 \\
\hline \multicolumn{9}{|l|}{ Vertical Strips:Varieties (8) } \\
\hline$V_{1}$. F56 Prota Zin & $278 b$ & $48.3 c$ & $94.4 \mathrm{c}$ & $101.4 \mathrm{c}$ & $113 d$ & $28.29 b$ & $38.14 \mathrm{dc}$ & $47.25 \mathrm{~d}$ \\
\hline$V_{2} \cdot$ MTU1010 & $281 b$ & $49.8 b$ & $93.7 \mathrm{c}$ & $99.8 d$ & $133 a$ & $28.22 b$ & $43.17 b c$ & $52.10 \mathrm{~b}$ \\
\hline $\mathrm{V}_{3}$. IGKV R2 & $286 a$ & $49.5 b c$ & $97.3 \mathrm{ab}$ & $102.9 \mathrm{~b}$ & $135 \mathrm{a}$ & $28.29 b$ & $44.86 a$ & $59.34 \mathrm{a}$ \\
\hline $\mathbf{V}_{4}$. Karma Masuri & $287 a$ & $49.9 b$ & $97.8 \mathrm{a}$ & $105.1 \mathrm{a}$ & $122 \mathrm{c}$ & $21.12 \mathrm{f}$ & $43.68 b$ & $51.31 \mathrm{~b}$ \\
\hline$V_{5}$. Mahamaya & $290 a$ & $48.6 b$ & $96.6 b$ & $103.7 b$ & $129 b$ & $30.15 a$ & $44.85 \mathrm{a}$ & $45.06 \mathrm{e}$ \\
\hline$V_{6 .}$ IR 36 & $260 c$ & $44.8 \mathrm{~d}$ & $82.0 \mathrm{e}$ & $90.9 \mathrm{e}$ & $108 \mathrm{e}$ & $24.25 d$ & $38.59 d$ & $42.41 \mathrm{f}$ \\
\hline$V_{7 .}$ IR 64 & $281 b$ & $46.7 \mathrm{c}$ & $89.9 d$ & $98.9 d$ & $122 \mathrm{c}$ & $27.43 c$ & $42.95 c$ & $50.81 \mathrm{cb}$ \\
\hline V. $_{\text {8. Indira Aerobic }}$ & $293 a$ & $52.2 \mathrm{a}$ & $96.1 \mathrm{~b}$ & $102.8 b c$ & $117 d$ & $22.41 \mathrm{e}$ & $37.79 \mathrm{e}$ & $38.19 f$ \\
\hline $\mathrm{CD}(5 \%)$ & 8.71 & 1.56 & 1.14 & 1.50 & 3.16 & 0.47 & 0.75 & 1.70 \\
\hline $\begin{array}{l}\text { Interaction Vat each level of } T \\
\text { Tat each level of } V\end{array}$ & $\begin{array}{l}3.80 \\
2.95\end{array}$ & $\begin{array}{l}0.84 \\
0.56\end{array}$ & $\begin{array}{l}0.69 \\
0.53\end{array}$ & $\begin{array}{l}0.75 \\
0.55\end{array}$ & $\begin{array}{l}1.08 \\
0.93\end{array}$ & $\begin{array}{l}\text { NS } \\
\text { NS }\end{array}$ & $\begin{array}{l}0.39 \\
0.26\end{array}$ & $\begin{array}{l}0.82 \\
0.64\end{array}$ \\
\hline
\end{tabular}


Table.3 Effect of nutrient management approaches on Nutrient uptake, Nutrient use efficiency and BCR

\begin{tabular}{|c|c|c|c|c|c|c|c|}
\hline \multirow[t]{2}{*}{ Treatments } & \multicolumn{3}{|c|}{ Nutrient Uptake } & \multicolumn{3}{|c|}{ Nutrient Use Efficiency } & \multirow[t]{2}{*}{ BCR } \\
\hline & $\mathbf{N}$ & $\mathbf{P}$ & $\mathbf{K}$ & $\mathbf{N}$ & $\mathbf{P}$ & $\mathbf{K}$ & \\
\hline \multicolumn{8}{|l|}{ Horizontal Strips: Fertilizer Treatment (5) } \\
\hline $\begin{array}{l}\text { T1 Fertilizer dose for yield Target } 6 \\
\text { ton/ ha + FYM }\end{array}$ & $111.3 \mathrm{~A}$ & $13.51 \mathrm{~A}$ & $127.2 \mathrm{~A}$ & 0.414 & 0.221 & 1.194 & 6.06 \\
\hline $\begin{array}{l}\text { T2 Fertilizer dose for yield Target } 5 \\
\text { ton/ ha + FYM }\end{array}$ & $93.0 \mathrm{~B}$ & $11.53 \mathrm{C}$ & $107.3 \mathrm{C}$ & 0.403 & 0.204 & 1.074 & 5.40 \\
\hline T5 GRD 12:60:40 & $84.4 \mathrm{C}$ & $12.59 \mathrm{~B}$ & 113.7B & 0.381 & 0.182 & 1.365 & 6.93 \\
\hline T4 FYM@5 t ha ${ }^{-1}$ & $43.8 \mathrm{D}$ & $9.75 \mathrm{D}$ & 68.7D & 0.203 & 0.152 & 0.326 & 2.26 \\
\hline T3 Control (No fertilize & $38.7 \mathrm{E}$ & $7.81 \mathrm{E}$ & $52.4 \mathrm{E}$ & & & & \\
\hline CD $(5 \%)$ & 1.84 & 0.98 & 4.35 & & & & \\
\hline \multicolumn{8}{|l|}{ Vertical Strips:Varieties (8) } \\
\hline$V_{1}$. F56 Prota Zin & $73.0 \mathrm{e}$ & $11.67 \mathrm{ab}$ & $93.4 \mathrm{c}$ & 0.324 & 0.198 & 0.957 & 4.34 \\
\hline $\mathrm{V}_{2 \cdot}$ MTU1010 & $76.9 c$ & $11.95 \mathrm{a}$ & $99.3 b$ & 0.372 & 0.200 & 1.191 & 5.60 \\
\hline $\mathrm{V}_{3 .}$ IGKV R2 & $82.8 \mathrm{a}$ & $11.22 \mathrm{~b}$ & $107.2 \mathrm{a}$ & 0.381 & 0.168 & 1.046 & 5.72 \\
\hline$V_{4}$. Karma Masuri & $78.6 \mathrm{~b}$ & $10.98 \mathrm{c}$ & $97.3 \mathrm{bc}$ & 0.415 & 0.213 & 1.087 & 5.79 \\
\hline$V_{5 .}$ Mahamaya & $76.0 \mathrm{~cd}$ & $11.03 \mathrm{c}$ & $90.2 c$ & 0.367 & 0.200 & 0.891 & 5.70 \\
\hline$V_{6}$. IR 36 & $67.5 \mathrm{f}$ & $10.61 d$ & 87.4 & 0.296 & 0.181 & 0.909 & 4.33 \\
\hline$V_{7 .}$ IR 64 & $75.3 \mathrm{~d}$ & $10.85 \mathrm{~cd}$ & $98.6 b$ & 0.336 & 0.201 & 1.117 & 5.34 \\
\hline$V_{8}$. Indira Aerobic & $63.9 \mathrm{~g}$ & $10.00 \mathrm{e}$ & $77.3 \mathrm{~d}$ & 0.312 & 0.159 & 0.719 & 4.47 \\
\hline $\operatorname{CD}(5 \%)$ & 1.52 & 0.44 & 4.72 & & & & \\
\hline $\begin{array}{l}\text { Interaction } V \text { at each level of } T \\
T \text { at eachlevel of } V\end{array}$ & $\begin{array}{l}0.82 \\
0.63\end{array}$ & $\begin{array}{l}0.27 \\
0.16\end{array}$ & $\begin{array}{l}1.95 \\
1.53\end{array}$ & & & & \\
\hline
\end{tabular}


The data clearly show that KUE is very high and in most of the cases more than 100 per cent have been recorded. Such type of KUE is misleading because of low crop response to applied fertilizer K due to well soil K supply. The available $\mathrm{K}$ of the experimental field soil was in high status. Hence such level of KUE can be stated as indefinable. The similar results have also been reported by many workers like (Ray et al., 2000) Bera et al., (2006) who stated that the contribution of K from fertilizer for maize was higher in comparison to soil. The higher $\mathrm{K}$ values could be due to interaction effect and primary effect of starter $\mathrm{K}$ doses in the treated plot, which might have caused the release of $\mathrm{K}$ from soil pools, resulting in the higher uptake from the native soil sources by the crop (Ray et al., 2000). Similar types of higher efficiency of K fertilizer were also reported in rice by Ahmed et al., (2002) in alluvial soils and for finger millet by Kadu and Bulbule (2007).

\section{Economics and profitability}

Net profit has been estimated taking the rates of one $\mathrm{kg} \mathrm{N}$ as Rs 12.85, P as Rs 56.25 and $\mathrm{K}$ Rs 31.50 and Rs 3500 for 5 tons FYM. The minimum support prize of rice was taken as Rs 1850 per quintal.

The highest net profit obtained in T1 (YT 6t/ha) which is Rs 48751 followed by GRD (Rs 36472) an T2(50q/ha) i.e. Rs 33174. Among the varieties, Karma Masuri produced higher net profit (Rs $35060 \mathrm{ha}^{-1}$ ) followed by IGKV R2, Mahamaya, MTU-1010, IR-64. These varieties have produced the desired yield level as per the STCR norms and hence their net profits were also identical. This indicated that net return as $\mathrm{Rs} / \mathrm{Re}$ spent on STCR based fertilizer application of T1 gave better results than all others treatments. So STCR target yield 6t/ha treatments obtain higher yield, net profit compare to other treatments due to balanced supply of nutrients from fertilizer, efficient utilization of applied fertilizer nutrients in the presence of organic sources and the synergistic effect of the conjoint addition of various sources of nutrients (Sellamuthu et al., 2015; Muralidharudu et al., 2011 and Singh and Singh, 2014. This result shows that the importance of soil test-based balance fertilization with targeted yield approach for maintenance of soil Fertility.Highest B:C Ratio was recorded with $\mathrm{T}_{5}$ (GRD) which received the fertilizer application as 120:60:40 kg NPK/ha followed by $\mathrm{T}_{1}, \mathrm{~T}_{2}$ and $\mathrm{T}_{4}$ treatments. This highest BC Ratio with $\mathrm{T}_{5}$ could be mainly due to application of inorganic fertilizer N,P and $\mathrm{K}$ without FYM as compared to STCR yield target of 60 and $50 \mathrm{q} / \mathrm{ha}$ which received fertilizer application with 5 t/ha FYM and high cost of FYM applied was also included with cost of inorganic fertilizers. Similar reports were also stated by Reddy and Ahmed 2000, Gogoi et al., 2011, Basavaraja et al., 2017).

Based on the study, it can be concluded that IGKV-R2, Karma Masuri, Mahamaya and IR64 achieved the yield target of 60 and 50q/ha proved to be a suitable to use the targeted yield equations generated for MTU-1010. Other varieties F56 Prota Zin, Indira Aerobic and IR-36 could not achieve the targeted yields. The application of fertilizers based on the soil test crop response correlation concept (developed for MTU-1010) to achieve a desired yield target used for other similar rice varieties exhibited higher fertilizer use efficiency for applied N P and K along with FYM application Although the B:C Ratio in terms of $\mathrm{Rs} / \mathrm{Re}$ spent on fertilizer was recorded higher with GRD (120:60:40 kg/ha NPK) without FYM due to which minimum cost of fertilizer input contributed higher BC ratio. However, soil test-based fertilizer integrated with FYM gave more $\mathrm{B}: \mathrm{C}$ ratio and net profit. 


\section{References}

Ahmed, S., Riazuddin, M., Krishna Reddy, P.V., 2002. Optimizing fertilizer doses for rice in alluvial soils through chemical fertilizers, farm yard manure and green manure using soil test values. Agropedology, 12:133-140.

Awan, T.H., Ali, R.I., Manzoor, Z., Ahmad, M. and Akhtar, M. 2011.Effect of different nitrogen levels and row spacing on the performance of newlyevolved medium grain rice variety, ksk-133. The Journal of Animal \&Plant Sciences, 21(2): 231234.

Banik., P. K. Ghosal, T. K. Sasmal, S. Bhattacharya, B. K. Sarkar and D. K. Bagchi. 2006. Effect of Organic and Inorganic Nutrients for Soil Quality Conservation and Yield of Rainfed Low Land Rice in Sub-Tropical Plateau Region. Journal of Agronomy and Crop Science. Vol. 192, No. 5. pp. 331-343

Basavaraja, P. K., Saqeebulla, H. M., Dey, P. and Prakash, S.S. 2016. Fertilizer prescription equations for targeted yield of rice (Oryza sativa L.) and their validation under aerobic condition. International Journal of Agriculture Sciences, Vol. 8(4),1003-1008

Belete, F., Dechassa, N., Molla, A., \& Tana, T. 2018. Effect of split application of different $\mathrm{N}$ rates on productivity and nitrogen use efficiency of bread wheat (Triticum aestivum L.). Agriculture \& Food Security, 7(1) 92.

Berra R, Seal A, Bhattacharyya P, Das TH, Sarkar D, Kangjoo K. 2006. Targeted yield concept and framework of fertilizer recommendation in irrigated rice domains of subtropical India. J Zhejiang Univ. Sci. 7(12):963- 968.

Chand, Gulab, Bajpai, R.K., Sahu, Shashikant, Paikra, Madan Prasad and
Patel, Himanshu. 2016. Varietal performance of rice for their yield and its attributes in farmers field of Durg. Asian J. Bio. Sci., 11 (1): 241-243.

Choudhary AK, Singh A, Yadav DS. 'On Farm Testing' of wheat cultivars for sitespecific assessment under varied bio-physical regimes in mid-hill conditions of Mandi district of Himachal Pradesh. Journal of Community Mobilization and Sustainable Development. 2010; 5(1): 1-6.

Das, K. N., Basumatary, A. and Ahmed, S. 2016. Targeted yield precision model assessment for rice-rice crop sequences in Farmers' Fields in Humid, Sub-tropical Northeastern India. Journal of soil Science and plant nutrition 16(1): 48-59.

Debarti, B., Gautam, Poonam.2013. Optimization and validation of targeted yield equation-based fertilizer doses under INM for wheat in Tarai region of Uttarakhand. Indian Journal Agricultural Sciences 47 (1): 16-25.

Gogoi A, Mishra A. 2015.Evaluation of STCR targeted yield approach on pumpkin (Cucurbita moschata) under ricepumpkin cropping system. International journal of Tropical Agriculture.; 33(2):1583-86.

Gautam, Poonam. Srivastava, Ajaya. Singh, Sobaran and Saxena, Anil. 2012. Targeted yield approach under integrated nutrient management for assessing fertilizer requirement of rice. Oryza Vol. 49 No. 1, (35-38).

Hossain A T, Rahman F, Saha P K and SolaimanA R M. 2010. Effects of different aged poultry litter on the yield and nutrient balance in boro rice cultivation. Bangladesh Journal of Agricultural Research 35(3): 497-505.

Ibajanai, K. 2017. Long term effect of prescription-based fertilizer 
application on soil carbon and potassium dynamics under maize wheat cropping system in an acid Alfisol.

Karki. Sangita, Sharma. Nabin, Bhusal. Gopal, Simkhada. Suresh, Regmi. Bhishma Raj, Adhikari. Bhuwan, and Poudel. Sanjok, 2018. Growth Parameter and Yield Attributes of Rice (Oryza Sativa) as Influenced by Different Combination of Nitrogen Sources." World Journal of Agricultural Research, vol. 6, no.2. 58-64.

Kadu, P., and Bulbule, A. (2007). Nutrient requirements of finger millet based on soil test crop response correlation approach.

L. P. Yuan, 1999. Hybrid Rice Breeding for Super High Yield. Hybrid Rice. Vol. 12, No. 6, pp. 1-6.

Mahmud, A.J., Shamsuddoha, A.T.M. and Nazmul, H.M. 2016. Effect of Organic and Inorganic Fertilizer on the Growth and Yield of Rice (Oryza sativa L.). Nature and Science 14(2): 45-54.

Muralidharudu Y, Mandal BN, Sammi Reddy K, Subba Rao A. 2011. In Progress Report of the All India Coordinated Research Project for Investigation on Soil Test Crop Response Correlation, Indian Institute of Soil Science, Bhopal, 11-61

Olsen, S.R., Cole, C.V., Watnable, F.S. and Dean, L.A. 1954. Estimation of available phosphorous in soils by extraction with sodium carbonate. U.S.D.A. Cir. No. 933:1-10.

Pradeep G, Channanaik D, Rajanna G A, Sannathimmappa H G, Ramesha Y M and Veeresha. 2012. Economics and nutrient uptake of rice (Oryza sativa) as influenced various levels of FYM and cattle urine application in Bhadra command area of Karnataka. Crop Research 43(1/3): 10-14
Ramalakshmi, Ch. S. Rao, P. C., Sreelatha, T., Mahadevi, M., Padmaja, G., Rao, P. V. and Sireesha, A. 2012. Nitrogen use efficiency and production efficiency of rice under rice-pulse cropping system with integrated nutrient management. J. Rice Res. 5(1 and 2): 42-51.

Ramamoorthy, B., R. L. Narasimham, and R. S. Dinesh. 1967. Fertilizer application for specific yield targets of Sonora 64. Indian Farming 17(5): 43-44.

Ray, P.K., Jana, A.K., Maitra, D.N., Saha, M.N., Chaudhury, J., Saha, S., Saha, A.R., 2000. Fertilizer prescriptions on soil test basis for jute, rice and wheat in Typic Ustochrept. Journal of Indian Society of Soil Science, 48:79-84.

Reddy, C.K., Riazuddin, M., Ahmed, S., 2000. Soil test-based fertilizer recommendation for maize grown in inceptisols of Jagtiyalin Andhra Pradesh. Journal of Indian Society of Soil Science, 48:84-89.

Sandhu, S. S., \& Mahal, S. S. 2014. Performance of rice (Oryza sativa) under different planting methods, nitrogen levels and irrigation schedules. Indian Journal of Agronomy, 59(3), 392-397.

Sathish, A., Govinda, G. V., Chandrappa, H. and Nagaraja, K. 2011. Long term effect of integrated use of organic and inorganic fertilizers on productivity, soil fertility and uptake of nutrient in rice and maize cropping system. International J. Sci. and Nature. 2: 8488.

Sellamuthu KM, Santhi R, Maragatham S, Dey P. 2015. Validation of soil test and yield target-based fertilizer prescription model for wheat on inceptisol. Research on Crops. 16(1): 53-58. 10.

Siddaram M K, Manjunatha B N, Jagadeesha N, Basavaraja M K and Ramulu. 2011. 
Effect of nitrogen levels through organic sources on dry matter production and nutrient uptake of irrigated aerobic rice (Oryza sativa L.). Mysore Journal of Agricultural Sciences 45(1): 191-193.

Shekara, B. G., Bandi, A. G., Shreedhara, D., \& Krishnamurthy, N. (2011). Effect of irrigation schedules on growth and yield of aerobic rice under varied levels of farm yard manure. ORYZAAn International Journal on Rice, 48(4), 324-328.

Singh YV, Singh SK. 2014. Fertilizer prescription for targeted yield of rice (Oryaza sativa L var. Saryu-52) in and Inceptisol of Varanasi. Indian Journal of Ecology. 41(2):282-285.

Peng, S., K. G. Cassman, S. S. Virmani, J. Sheehy and G. S. Khush.1999. Yield Potential Trends of Tropical Rice since Release of IR8 and the Challenge of Increasing Rice Yield Potential. Crop Science. Vol. 39, No. 6, pp. 1552-1559.
Srivastava, O.P. 2013. Integrated nutrient management for sustained fertility of soil. Ind. J. Agric. Chem. 31(1): 1-12.

Subehia, S.K. and Sepehya, S. 2012. Influence of long-term nitrogen substitution through organics on yield, uptake and available nutrients in a ricewheat system in an acidic soil. Journal of the Indian Society of Soil Science 60(3): 213-217.

Subbiah, B.V and Asija, G.C. 1956. A rapid method for the estimation of nitrogen in soil. Curr. Sci., 25: $259-260$

Swarup Sr, A. 2006. Imapct of 10-Year RiceWheat Cropping System and Integrated Nutrient Management on Soil Properties and Crop Productivity in a Gypsum Amended Sodic Soil. In The 18th World Congress of Soil Science.

Tiwari K.R., Sitaula B.K., Bajracharya R.M. and Borresen T. 2010. Nutrient Cycling in Agro-ecosystems, 86(2), 241-253.

\section{How to cite this article:}

Monika Tikariha, V. N. Mishra, L. K. Srivastav, R. Banwasi and Jatav, G. K. 2020. Suitability of Targeted Yield Equations Evolved for MTU-1010 to Other Similar Rice Cultivars in Chhattisgarh. Int.J.Curr.Microbiol.App.Sci. 9(11): 1516-1527. doi: https://doi.org/10.20546/ijcmas.2020.911.180 